\title{
DEVELOPMENT OF SCIENTIFIC INFORMATION RESOURCES AND SERVICES
}

\author{
N.U. YAPA* \\ International Irrigation Management Institute, 126, Sunil Mawatha, Pelawatte, \\ Battaramulla.
}

(Received: 05 May 1998; accepted: 02 October 1998)

\begin{abstract}
S \& T organizations are expected to take appropriate actions for developing information resources to support research and development activities. Libraries and information centres are created by these orsanizations to satisly the information needs of its $R$ \& D personnel. A national plan should be drawn up to identify the strengths and weaknesses of the resources and needs of the scientific community and to formulate a national policy for development of information collections.

In the late $1960 \mathrm{~s}$, provision of scientific information was confined to a few special and university libraries which were available only to the institutional staff. Cooperation among the libraries was limited to personal contacts. Due to inadequate financial resources, lack of cooperation among the libraries, lack of a national colfection development plan, lack of scientific library professionals, absence of national scientific documentation service, information development progress was slow.

The National Science Council of Ceylon (NSC), which was established in 1.968, had a main responsibility to select and disseminate scientific and technical information. NSC set up the Sri Lanka Scientific and 'Technical Information Centre (SLSTIC) in 1977. SLSTIC contributed towards development of national science information infrastructure by creating a national network of scientific libraries; organizing resource sharing programmes; operating bureau services; conducting library education programmes; engaging in scientific documentation. SLSTIC had made a significant impact on library automation, library development, library education, bibliographical standarclization, library research and library cooperation.
\end{abstract}

Keywords: Information centres, information policy, science information.

\section{SCIENTIFIC INFORMATION}

Information is widely recognized as a resource that should be captured, organized and developed with the objective of satisfying the current as well as the future needs of the users. Like other types of resources, a collection of information, which is stagnant and static is considered not worth retaining. Value of information depends not only on its accuracy, comprehensiveness and currency, but also on its extent of use. Development of information to make it a useful, easily accessible and readily available resource is hindered by the

\footnotetext{
"Chairman, Steering Committee on Scientific \& Technical Information, NARESA.
} 
misconceptions associated with it. Many planners, policy makers, and administrators believe that information collections would grow naturally without professional intervention and that no special managerial skills or techniques are required to handle them. On the other hand, they undoubtedly accept the fact that research and development work cannot be performed effectively without appropriate information and that lack of such information would lead to delays, duplication and wastage.

Although philosophically and theoretically the impact on and the role of, information in development activities is accepted, it is rarely reflected in national plans, development programmes, performance evaluations and governance papers. In most instances, these policy and strategic documents hardly show any provision for planning and development of information resources. Low priority and attention given to information has led to the creation of obsolete, irrelevant, scattered and unutilized information resources which do not have any impact on the socio-economic development of the country.

In contrast to this situation, a rapidly developing country like Singapore, firmly accepts the importance of information resource development and the role that it should play in building the nation. The national development plan of Singapore clearly states "...the future belongs to countries where people make most productive use of information, knowledge and technology..., knowledge and information will be the engines that drive the economy in the 21 st century".

The above mentioned facts are more relevant to science and technology. S\&T organizations are expected to take appropriate actions for developing information resources to support research and development activities. Scientific information (including technical information), differs from other branches of information in the method of acquisition, analysis, organization and utilization.

These methods are guided by three special characteristics of scientific information, namely, objectiveness, authority and universality. It is important that planners and developers of scientific information systems take these characteristics into consideration. Scicntific information is the objective information of the universe and its phenomena, generated by scientific method of inquiry and validated to conform to empirical observations of natural phenomena. Every new addition to the store of objective information is an extension to the existing information resources. New information will replace previous information and makes the knowledge based on such information obsolete. Hence scientific information resources should be updated regularly. Universality of information makes it adaptable and applicable throughout the world, disregarding its origin, language and form of presentation. Scientific information is not considered valid unless it is evaluated and accepted by the scientific community. Scientists are careful in guaranteeing the high standard 
of scholarship and quality of work reported in scientific literature. Research results submitted by scientists for publication in scholarly journals are refereed by a panel of experts to ensure accuracy and quality. Any information resource which has been developed disregarding the above mentioned characteristics would not be accepted by scientific information users.

Scientific organizations that are engaged in $R \& D$, develop information resources mainly to support their own activities. Libraries and information centres are created by these organizations to satisfy the information needs of R\&D personnel. It is practically impossible for any organization to develop information systems to satisfy all its information needs using only its own resources. Hence, it is necessary to establish links with external organizations so that their information resources too could be accessed. The Information resources scattered throughout the country could be put to optimum use of the scientific community by linking them to a national system. A national plan should be drawn up to identify the strengths and weaknesses of the resources and needs of the scientific community and to formulate a policy for developing information collections.

Foreseeing the need of a national plan for the development of scientific information resources and services, the Government of Sri Lanka in 1967 sought assistance of UNESCO to design a national information system.

\section{SCIENTIFIC INFORMATION PROVISION IN $1960 \mathrm{~s}$}

In the late 1960s, at the time the National Science Council (NSC) was established, provision of scientific information was confined to a few special and university libraries. These libraries were operating on individual basis without being concerned with the services and needs of the other libraries. Coordination among the libraries was restricted to personal contacts of librarians. This led to creation of specialized and small collections of scientific literature which were available, accessible and known to the scientists attached to the institution concerned.

There were only a few scientific libraries in the country. Department of Agriculture had a central library with over 50,000 monographs and 2000 journals, at the Central Agricultural Research Institute (CARI) in Gannoruwa to serve an island-wide network of agricultural research centres. Like other libraries in the country, due to financial constraints, the CARI library encountered difficulties in acquiring current literature. Acquisition of journals was confined to exchanges. The services of the library were available only to the departmental staff. The library had no extension service to serve the outstation staff in the agricultural sector. The crop research institutes had libraries which catered to their own needs. The oldest and biggest was the Library attached to 
the Tea Research Institute (TRI) in Talawakelle which had 20000 monographs in its collection. Being isolated in location and specialized in collection, TRI had given special attention to develop its library. Coconut and Rubber Research Institutes too had well-organized libraries with specialized collections. There was an unwritten agreement among the crop research libraries for the exchange of material and for inter-library lending. The technical library attached to the Ceylon Institute of Scientific \& Industrial Research (CISIR) had a collection of over 20000 monographs. This was the largest science library in Colombo and it was the only reliable source of information accessible to the scientists attached to institutions which had no organized libraries. The library covered a wide range of scientific and technical subjects, possessed a strong collection of reference material and was open to external users as well. These characteristics of the library prompted scientists to consider the CISIR library as the main source of scientific information. In fact, it was the de facto national science library of the country. In the university sector, the University of Ceylon had a network of campus and faculty libraries with fairly large collections of scientific literature. The Universities of Vidyodaya and Vidyalankara had relatively small collections of scientific literature. Apart from the above mentioned, there were no more than 10 scientific libraries which had substantial collections. The British Council and the United States Information Service (USIS) operated libraries in Colombo and Kandy, which were mainly catering to the needs of the general public and students.

Scientific information provision in Sri Lanka was confined to a few institutional collections, which were available only to the institutional staff. Cooperation among the libraries was limited to personal contacts. Analysis of above scenario reveals that the inefficient and ineffective provision of scientific information in late 1960s could be attributed to five main problems:

a) inadequate financial resources: Total annual budget allocated for the purchase of books and journals by scientific libraries was below US $\$ 250000$. Libraries were given low priority in budget allocations. Often library funds were transferred to other headings to offset unexpected expenditure. This practice adversely affected the collection development work of libraries.

b) lack of cooperation among the libraries: Scientific libraries were operating individually attempting to become self sufficient in information. This is an impossible task even for a library with rich financial and human resources. No national plan for library cooperation existed for sharing and exchange of library resources. As photocopying facilities were not available in most libraries, inter-library lending which was operated on personal contacts was the only possible resource sharing activity. 
c) lack of a national collection development plan: scientific libraries developed their collections without taking national requirements into consideration. As a result of this, the national collection had gaps and there was duplication. Resources available to the libraries could have been utilized rationally if there had been consensus in library acquisitions. There were several leading scientific organizations without organized libraries. A national programme for the development of information infrastructure would have immensely helped these organizations.

d) Lack of scientific library professionals: Scientific librarianship was a specialized profession which required both professional skill and subject knowledge. Salaries and benefits offered to science librarians were not attractive to draw the best talent. Science libraries, except for'a few, were managed by non-scientific personnel. They had not been able to compile analytical catalogues to provide specialized and personalized information services. A national programme to produce science librarians was not available.

e) Absence of a national scientific documentation service: The National Library Services Board and the National Archives acquired books and serials published in the country under the legal deposit law. There had been no programme to collect unpublished documents. In provision of scientific information, gray literature or unpublished documents play an important role. It is recognized that technical reports, research papers, conference documents, etc. carry valuable and highly specialized information that are often not available in published sources. A national programme to collect and preserve unpublished scientific documents was not available.

Even the above problems had not been clearly identified, the government felt the need of improving the national scientific information system to support research and development activities of the country.

The first attempt to devclop a national plan for scientific information was made in 1967. The Government of Sri Lanka (then Ceylon) through the Department of Foreign Aid requested UNESCO to provide the services of an expert to assist the government in developing a national plan. The expert was expected to conduct a survey of existing resources, design an information infrastructure to link the resources and identify the services that should be available to the scientists. He was further expected to draw up a project proposal to seek funds for implementing his recommendations. Mr L.E. Samarasinghe, a Sri Lankan information scientist attached to UNESCO, was assigned this task. 
Samarasinghe submitted his report in March 1969. With the view of coordinating the existing scientific information resources and organizing a national programme for acquisition, exchange and dissemination of scientific literature, he recommended "... measures be taken as early as possible to set up a national scientific and technical documentation centre which will, inspite of the name, function both as a documentation centre and as a national science library". The functions of the centre were similar to those of the centres in the region such as India (INSDOC), Pakistan (PANSDOC), Iran (IRANDOC), Iraq (IRAQDOC) and Turkey (TURDOC). The proposed centre was named Ceylon National Scientific and Technical Documentation Centre (Ceynsdoc).

It was recommended to establish Ceynsdoc as an autonomous body under the National Science Council of Ceylon. The centre was to be managed by a director under a governing board appointed by NSC. The report did not clearly define the relationship between NSC and Ceynsdoc.

A project proposal seeking financial support for the establishment of Ceynsdoc was submitted to UNDP in October 1969. This was withdrawn within a few months due to other national priorities.

\section{UNISIST CONCEPT}

The National Science Council of Ceylon, which was established in 1968, had a responsibility 'to select and disseminate information relating to scientific and technical matters and to publish reports, periodicals and papers on matters scientific and technical'. This did not give NSC the mandate to serve as the national scientific information provider. However, since NSC had the responsibility to promote scientific research, it undertook the responsibility of setting up a national science information system to support research activities.

In 1972, NSC revised the proposal to establish Ceynsdoc by dropping the idea of its functioning as the national science library. Two factors affected this decision. Firstly, the National Library Services Board was planning to set up a national library which would also cover science and technology. Secondly, it was argued that a virtual national science library could be created rather than physically building a central collection, by coordinating the existing collections of scientific literature. This proposal too was deferred by the Government as information provision received low priority.

UNESCO and the International Council of Scientific Unions, in 1974, launched a programme to improve global scientific information provision by facilitating speedy and systematic exchange and transfer of scientific information. This programme which was known as UNISIST, encouraged the member states to initiate national infrastructure comprising three components: 
a) NATIS : a national scientific and technical information network by linking scientific information resources in the country.

b) STIC: a national scientific and technical information centre to serve as the coordination centre of the national network.

c) UNISIST Committee: a national committee to advice STIC on NATIS activities.

UNESCO expected to link the national information infrastructures to create a global information system named UNISIST. UNESCO and ICSU organized conferences, workshops and training programmes to promote the UNISIST programme. Guidelines on various aspects of information provision were prepared.

In the light of the UNISIST concept, NSC revised the project proposal in 1976 and submitted it to the United Nations Development Programme (UNDP) seeking financial support. In the meantime in 1977, NSC set up the Sri Lanka Scientific and Technical Information Centre (SLSTIC) and appointed the Sri Lanka UNISIST Committee. UNDP accepted the project proposal in 1978.

\section{SCIENTIFIC INFORMATION PROVISION BY SLSTIC}

SLSTIC started functioning in May 1977 by operating services that could be organized with the available resources. When the UNDP project was started in 1978, these services were expanded and strengthened. The activities of SLSTIC that contributed towards development of national science information infrastructure are enumerated below under five main topics.

\section{Networking}

Creation of a national network of scientific libraries (NATIS) was the key task of SLSTIC. Main idea of the network was to integrate the resources of various libraries to provide more useful services to the scientific community. The network was formed at the first meeting of science librarians which was held on 28 June 1977. The network was designated the Sri Lanka Scientific and Technical Information Network (SLSTINET). 40 libraries were in SLSTINET in 1977. The membership increased gradually and by end of 1997 there were 120 member libraries. SLSTINET created a forum for science librarians to discuss common problems, formulate standards and draw up cooperative programmes.

When the membership grew, the necessity of dividing the genera] network into smaller groups to provide specialized and personalized information services arose. Libraries having common subject interest or libraries which served users who were interested in a particular subject, were grouped to form sub-networks. SLSTIC planned four sub-networks for agriculture, medicine, industry and 
environment. Agricultural network (AGRINET) was formed in 1983. The medical network was named Health Literature Library and Information Service (HeLLIS) to serve as the Sri Lanka wing of the global health information network created by the World Health Organization. Environmental Library Network (ENLINET) was organized in 1991 by the Central Environmental Authority with the support of SLSTIC. Setting up of an information network for industry was delayed due to logistic problems. The strategy of NSC was to initiate the sub-networks and to assign coordination to an appropriate institution. A steering committee comprising the coordinators of sub-networks was appointed to ensure integrity of the national scientific information infrastructure.

\section{Cooperative programmes}

With the view of pooling the resources available in the network of libraries for. providing better services to the scientific community, SLSTIC designed two types of joint programmes: a) cooperative databases b) cooperative acquisition plans.

Co-operative databases: Central catalogues were compiled by merging the catalogue entries supplicd by the participating libraries on scientific documents available in their libraries. These databases were used for Inter library lending services, rationalization of acquisitions and creation of specialized collections. Two national catalogues were compiled:

UNICAST - union catalogue of scientific and technical books. (More than 40 libraries participated in this programme).

UNILIST - union list of scientific and technical serials. (About 30 libraries participated in this programme).

These catalogues directly affected acquisition policies of libraries and compelled them to consider national requirements too. Gaps and duplicates in the national collection were disclosed by the catalogues.

Cooperative acquisition plans (CAP): A scheme was drawn up by SLSTIC to rationalize acquisition of scientific material. The scheme was started with scientific and technical abstracting journals, as they were the most expensive information sources acquired by a science library. Purpose of CAP was to minimize duplication and use the saved money to purchase new material. $35 \mathrm{~S} \& \mathrm{~T}$ abstracting journal titles were distributed among 20 science libraries. 


\section{Service Bureau}

With the view of supporting the science libraries in their training and promotional services, SLSTIC organized bureau services. Using UNDP funds, it acquired a variety of modern equipment and created several systems to support bureau services. These included an AV pool, a microfilming bureau, a printing press, a computer centre and a photocopying network. AV equipment with technical staff were hired out to libraries. An integrated microfiche system was established to film, duplicate, enlarge and print. Printing of scientific publications was undertaken at the Printing Press. Photocopying machines were placed at leading science libraries to promote document supply services.

\section{Personnel development}

Noting that the library education programmes available in the country were inadequate to train science librarians, SLSTIC designed Special Educational and Training Programmes (STEP). Some topics of STEP included scientific journal management, scientific and technical information sources, Science Citation Index, and Renewable Energy Information Services.

\section{Scientific documentation}

A national repository of scientific documents was created to deposit scientific documents by Sri Lankans or generated in Sri Lanka or relating to Sri Lanka. An indexing service was organized to retrieve the documents in the repository.

\section{IMPACT OF SLSTIC SERVICES}

SLSTIC was established and run by NSC and its successor NARESA, to improve scientific information provision in the country. SLSTIC was expected to play several roles in serving the scientific community as: coordinating centre by pooling the resources of science libraries, referral centre by dirccting querries to appropriate sources; documentation centre by collecting, analysing and indexing scientific documents; scrvice centre by providing a wide range of reprographic and $A V$ services; information centre by answering scientists queries using domestic and external sources; training centre by conducting workshops and seminars; science library by offering reader services on selected subjects; distribution centre for library software; national nodal point of global and regional international information networks.

No study has been done to evaluate the impact of SLSTIC on national information development. However, growth of activities and the response of the libraries indicated that SLSTIC had functioned as a change agent in the field of librarianship. Reviewing the history of librarianship in the past two decades, one 
would observe that SLSTIC had played a key role in all important events associated with information development.

Main areas of activities of SLSTIC that had affected information development could be identified under five broad topics: library automation, library cooperation, library education, library development and library research.

\section{Library automation}

SLSTIC had served as the pioneer in library automation in Sri Lanka. It had installed the first computerized library system in the country and had compiled the first bibliographic database. With the view of motivating other libraries in automation, SLSTIC selected coopcrative programmes for computerization. This facilitated library personnel of other libraries to familiarize themselves with computer applications.

Library automation work of SLSTIC prompted UNESCO to designate SLSTIC as the national distributing agency of its library software. UNESCO software named 'micro CDS/ISIS' was popular among the libraries in the developing countries. SLSTIC promoted the software which was distributed free of charge by conducting training and consultation services. In addition to these, a simplified manual on CDS/ISIS in English and Sinhala, and an integrated library system were made available to assist libraries in using the software. The impact of SLSTIC on library automation is evident from the rapid growth of the CDS/ISIS-based computerized library systems in the country.

In 1996, with SAREC funds, SLSTIC established a Local Area Network (LAN) with 15 workstations. It was linked to Lanka Educational Academic and Research Network (LEARN) and to the Internet. These facilitics allowed science libraries to communicate with SLSTIC by e-mail. A library can request a photocopy or an inter-library loan by e-mail and receive the photocopy by fax and search results by e-mail. In the near future, it would be possible for SLSTIC to provide Internet dial-up links to science libraries. Web sites of local libraries were linked to NARESA home page providing easy access to local information sources. Plans were being drawn up to expand the NARESA LAN by linking the research institutes in the vicinity using fiber optic lines.

\section{Library cooperation}

Prior to the establishment of SLSTIC, cooperation among libraries took place on a personal basis. A librarian had to contact a colleague librarian personally to obtain a document or to arrange a service. SLSTIC by organizing library consortia, formalized library cooperation. Cooperative programmes such as union catalogues, central bibliographies, rationalized acquisition, enhanced inter library cooperation. 
Library networks and cooperative programmes designed by SLSTIC had been used as models by other libraries. Network meetings created forums for librarians to discuss their problems, share experiences and demonstrate their systems. These meetings were used to formulate procedures, standards, and common guidelines. SLSTIC had been a meeting place for science librarians.

\section{Library education}

Science librarians needed a special training as they had to handle special material and special types of services. Since there was no suitable training in the country, SLSTIC had to design training programmes for this purpose. Since it had complete systems of photocopying, microfilming, printing, AV and computers, SLSTIC was recognized as a key training agency. Library professionals from both local and regional institutions visited SLSTIC to observe its activities. SLSTIC staff had to participate in external training programmes to share their experiences and knowledge.

\section{Libraxy development}

Necessity of strengthening the local science libraries was recognized by SLSTIC. It served as a clearing house for foreign funds. Foreign donors who wished to support research libraries. in collection development were happy to appoint NARESA/SLSTIC to distribute their grants. Most of the bureau services of SLSTIC were provided at cost or sometimes free of charge. Some equipment received from the UNDP project were donated to libraries to improve their services. SLSTIC staff provided consultation services to libraries in library automation, microforms, audio visuals etc.

\section{Libraxy Research}

Information science has been identified by NARESA as one of the subject areas for research grants. SLSTIC with the advice of the Steering Committee on Scientific and Technical Information monitored the information research projects. Research grants had been awarded for conducting surveys of information sources, compiling bibliographies, creation of databases etc.

\section{CONCLUSION}

The scenario of scientific information provision underwent rapid changes during the past two decades. Introduction of new information media and services made the existing systems obsolete. Online services, multimedia databases, internet connectivity have changed the philosophy, ethics and standards of librarianship. The library personnel need re-training and library systems need re-engineering. SLSTIC should lead the science libraries in facing; the challenges of information 
and communication technologies without lagging behind. SLSTIC should recognize the needs of the changing information society, should assess the existing systems to identify their weaknesses and strengths, should evaluate applicability of new media and should redesign information systems to get the maximum benefits of the new information technology.

\section{References}

1. Samarasinghe L.E. (1969). Ceylon National Scientific and Technical Documentation Centre. UNESCO, Paris.

2. Kodagoda N. (1978). A study on the application of scientific and technological information in development: field study in Sri Lanka. UNESCO, Paris.

3. Schwartz S. (1979). Developing scientific and technical information services in Sri Lanka. UNESCO, Paris.

4. D'Olier J. (1983). Sri Lanka Scientific and Technical Information Centre: project findings and recommendations. UNESCO, Paris.

5. Yapa N.U. (1984). Sri Lanka Scientific and Technical Information Centre. In: Delivering information to users : products, packages and promotions. (Ed. Ian Dickson). pp. 142-148. FID, Melbourne.

6. Samarajiwa R. (1987). From collection to access : a policy research report. NARESA, Colombo. 
JOURNAL OF THE

NATIONAL SCIENCE COUNCIL OF SRI LANKA

AUTHOR INDEX

VOL $26-1998$ 
Abeysekera A.M. see Nikawala J.K et al. (1998)

Abeytunga D.T.U., Peiris T.E.M.\& Wijesundera R.L.C. - Structure-antibacterial activitiy relationship of some aromatic acids 26: 133-139 (1998)

Adikaram N.K.B. see Kumar N.S. et al. (1998)

Ahmed N., Eunus M., Latif M.A., Ahmed Z.U. \& Rahman M. - Effect of nitrogen on yield, yield components and contribution from the pre-anthesis assimilates to grain yield of three photosensitive rice (Oryza sativa L.) cultivars 26: 35$45(1998)$

Ahmed Z.U. see Ahmed N. et al. (1998)

Alahakoun C.P. see de Costa D.M. et al. (1998)

Ali M.A. see Golam Sarwar A.K.M. et al. (1998)

Bandara A.M.P. see de Costa D.M. et al. (1998)

Bandara B.M.R. see Hewage C.M. et al. (1998)

Chandarananda W.P.N. see Piyasiri S. \& Chandrananda W.P.N. (1998)

Dahanayake C. \& Gunawardhana H.D. - Tertiary education in the physical sciences 26: $217-228$

de Alwis M.C.L. - Animal health research in Sri Lanka : a review of the past, future priorities and constraints 26: 151-162 (1998)

de Costa D.M., Wijayagunasekara H.N.P., Alahakoon C.P. \& Bandara A.M.P. Preliminary studies on the prevalence and controlling efficiency of Pasteuria penetrans, a parasite of Meloidogyne spp. in Sri Lanka 26: 47-57 (1998)

de Costa W.A.J.M. - Prediction of the effects of soil water stress on grain yield and radiation use efficiency of rice (Oryza sativa L.) using a simulation model $\mathbf{2 6}$ : 101-123 (1998)

Deraniyagala S.A., Wijesundera R.L.C. \& Weerasena O.V.D.S.J. - Antifungal activitiy of Ficus racemosa leaf extract and isolation of the active compound 26: 19-26 (1998)

Duddeck H. see Uzoukwu B.A. et al. (1998) 
Eunus M. see Ahmed N. et al. (1998)

Golam Sarwar A.K.M., Ali M.A. \& Karim M.A. - Correlation of grain characters in rice (Oryza sativa L.) 26: 209-216 (1998)

Gunawardhana H.D. see Dahanayake C. \& Gunawardhana H.D.(1998)

Hasan M.A. \& Kamal A.M.A. - Effect of fertilizers on grain yield and grain protein content of wheat 26: 01-08 (1998)

Hemingway J. see Karunaratne S.H.P.P. \& Hemingway J. (1988)

Hewage C.M., Bandara B.M.R., Karunaratne V., Wannigama G.P., Pinto M.R.M. \& Wijesundara D.S.A. - Antibacterial activity of some modicinal plants of Sir Lanka 26: 27-34 (1998)

Hewavitharanage P. see Kumar N.S. et al. (1998)

Jansz E.R. see Nikawala J.K. et al. (1998)

Jayasinghe S. \& Yapa G.- Research in the field of medical sciences 26: 275-281 (1.998)

Kamal A.M.A. see Hasan M.A. \& Kamal A.M.A. (1998)

Karim M.A. see Golam Sarwar A.K.M. et al. (1998)

Karunaratne S.H.P.P \& Hemingway J. - Identical restriction enzyme maps of the amplicon containing the Est $\alpha 2^{1}$ and Est $\beta 2^{1}$ insecticide resistance genes in. Culex quinquefasciatus colonies from Saudi Arabia, Tanzania and Sri Lanka 26: 311-319 (1998)

Karunaratne V. see Hewage C.M. et al. (1998)

Kulasiri Don see Punyawardena B.V.R (1998).

Kumar N.S., Hewavitharanage P. \& Adikaram N.K.B. - Histology and fungal flora of shot-hole borer beetle (Xyleborus fornicatus) galleries in tea (Camellia. sinensis) 26: 195-208 (1998)

Latif M.A. see Ahmed N. et al. (1998)

Liyanage A.S.U., Manawaprema M.M.C. \& Mendis M.H. - Differentiation of A \& B genome of banana and plantain (Musa spp.) by esterase enzyme 26: 125-131 (1998) 
Manawaprema M.M.C. see Liyanage A.S.U. et al. (1998)

Mendis M.H. see Liyanage A.S.U. et al. (1998)

Nikawela J.K., Abeysekara A.M. \& Jansz E.R. - Flabelliferins - steroidal saponins from palmyrah (Borassus flabellifer L.) fruit pulp I. Isolation by flash chromatography, quantification and saponin activity 26: 09-18 (1998)

Nikawala J.K., Wijeyaratne S.C., Jansz E.R. \& Abeysekera A.M. - Flabelliferins, steroidal saponins from palmyrah (Borassus flabellifer L.) fruit pulp 1I. Proliminary investigations of effect on yeast and selected bacteria26: 141150 (1998)

Okeke S.I. see Uzoukwu B.A. et cil. (1998)

Peiris T.E.M. see Abeytunga D.T.U. et al. (1998)

Perera N. see Piyasiri S. \& Prerea N. (1998)

Pinto M.R.M. see Hewage C.M. et al. (1998)

Piyasini S. \& Chandarananda W.P.N. - Studies on the population structure of zooplankton in the Kotmale reservoir 26: 59-76 (1998)

Piyasiri S. \& Perera N. - Species composition and population dynamics of phytoplankton community in Kotmale reservoix 26: 293-309 (1998)

Prelis S.P. - International co-operation in science \& technology 26: 249-274 (1998)

Punyawardena B.V.R. \& Kulasiri Don - Spatial interpolation of rainfall in the dry zone of Sri Lankia 26: 247-262(1998)

Ramasamy R.- Developments in biotechnology: progress, problems and prospects 26: $283-292(1998)$

Rahman M. see Ahmed N. et al. (1998)

Sirisena J.A. - Grafted sweet orange [Citrus sinensis (L.) Osbeck] influenced by variability in woodapple [Feronia limonia (L.) Swingle] rootstock 26: 185-194. (1998)

Uzoukwu B.A., Duddeck H. \& Okeke S.I. - Synthesis and spectroscopic studies of 4-adipoyl-bis (1-phenyl-3-methyl-pyrazolone-5) as a bis-(1,3-diketone) 26: 229-234 (1998) 
Wannigama G.P. see Hewage C.M. et al. (1998)

Watson M. - A review of the Man and the Biosphere programme in Sri Lanka 26: 163184 (1998)

Weerasena O.V.D.S.J. see Deraniyagala S.A. et al. (1998)

Wijayagunasekara H.N.P. see de Costa D.M. et al. (1998)

Wijesundara D.S.A. see Hewage C.M. et al. (1998)

Wijesundera R.L.C. see Abeytunga D.T.U. et al. (1998)

Wijesundera R.L.C. see Deraniyagala S.A. (1998)

Wijewardena J.D.H. - Effect of phosphorus sources and levels with particular emphasis on selectively mined Eppawela rock phos phate on vegetable production 26: 93-100 (1998)

Wijeyaratne S. C. - Temperature tolerance and other properties of two ethanol producing Saccharomyces cerevisiae strains isolated fiom cocon ut toddy 26:7791 (1998)

Wijeyaratne S.C. see Nikawala J.K. et al. (1998)

Yapa G. see Jayasinghe S. \& Yapa G. (1998)

Yapa N.U. - Development of scientific information resources and services 26 : 321-332 (1998)

Zubair L. - Variation of surface winds at Hambantota fiom April 1990 to March 1991 26: $235-246$ (1998) 
JOURNAL OF THE

NATIONAL SCIENCE COUNCIL OF SRI LANKA

\section{SUBJECT INDEX}

VOL 26 - 1998 


\section{Adipoyl pyrazolone}

Synthesis and spectroscopic studies of 4-adipoyl-bis(1-phenyl-3-methyl-pyrazolone5) as a bis-(1,3-diketone) (B.A. Uzoukwu, H. Duddeck \& S.I. Okeke) 26: 229$233(1998)$

\section{Alternaria sp.}

Antifungal activity of Ficus racemosa leaf extract and isolation of the active compound (S.A. Deraniyagala, R.L.C. Wijesundera \& O.V.D.S. Weerasena) 26: $19-26$ (1998)

\section{Ambrosia fungus}

Histology and fungal flora of shot-hole borer beetle (Xyleborus fornicatus) galleries in tea (Camellic sinensis) (N.S. Kumar, P. Hewavitharanage \& N.K.B. Adikalam) 26: 195-207 (1998)

\section{Amplicon}

Identical restriction enzyme maps of the amplicon containing the Esto $x^{2}$ and Est $32^{\prime}$ insecticide resistance genes in Culex quinquefasciatus colonies from Saudi Arabia, Tanzania and SriLanka (S.H.P.P. Karunaratne \& J. Hemingway) 26: 311-319 (1998)

\section{Animal health}

Animal health research in Sri Lanka : a review of the past, future priorities and constraints (M.C.L. de Alwis) 26: 151-161 (1998)

\section{Antibacterial activity}

Antibacterial activity of some medicinal plants of Sri Lanka (C.M. Hewage, B.M.R. Bandara, V. Karunaratne, G.P. Wannigama, M.R.M. Pinto \& D.S.A. Wijesundara) 26: 27-34 (1998)

Structure-antibacterial activity relationship of some aromatic acids (D.T.U. Abeytunga, T.E.M. Peiris \& R.L.C. Wijesundera) 26: 133-139 (1998)

\section{Antifungal activity}

Antifungal activity of Ficus racemosc leaf extract and isolation of the active compound (S.A. Deraniyayala, R.L.C. Wijesundera \& O.V.D.S. Weerasena) 26: $19-26$ (1998)

\section{Antimicrobial activity}

Flabelliferins, steroidal saponins from palmyrah (Borassus flabellifer L.) fruit pulp. II. Preliminary investigations of effect on yeast and selected bacteria. (J.K. Nikawala, S.C. Wijeyaratne, E.R. Jansz \& A.M. Abeysekera) 26: 141-150 (1998) 


\section{Aromatic acids}

Structure-antibacterial activity relationship of some aromatic acids (D.T.U. Abeytunga, T.E.M. Peiris \& R.L.C. Wijesundera) $26: 133-139$ (1998)

\section{Biological control}

Preliminary studies on the prevalence and controlling efficiency of Pasteuria. penetrans, a parasite of Meloidogyne spp. in Sri Lanka (D.M. de Costa, H.N.P. Wijayagunasekara, C.P. Alahakoon \& A.M. Priyantha Bandara) 26: 47-57(1998)

\section{Biosphere}

A review of the Man and the Biosphere programme in Sri Lanka (M. Watson) 26: $163-183$ (1998)

\section{Biotechnology}

Developments in biotechnology - progress, problems and prospects (Ranjan Ramasamy) 26: 283-292 (1998)

\section{Cabbage}

Effect of phosphorus sources and levels with particular emphasis on selectively mined Eppawela rock phosphate on vegetable production (J.D.H. Wijewardena) 26: 93-100 (1998)

\section{Calanoids}

Studies on the population structure of zooplankton in the Kotmale reservoir (Swarna Piyasiri \& W.P.N. Chandrananda) 26: 59-76 (1998)

\section{Camellia sinensis}

Histology and fungal flora of shot-hole borer beetle (Xyleborus fornicatus) galleries in tea (Camellia sinensis) (N.S. Kumar, P. Hewavitharanage \& N.K.B. Adikaram) 26: 195-207 (1998)

\section{Carboxylesterases}

Identical restriction enzyme maps of the amplicon containing the Est $\alpha 2^{1}$ and Est $\beta 2^{1}$ insecticide resistance genes in Culex quinquefasciatus colonies from Saudi Arabia, Tanzania and SriLanka (S.H.P.P. Karunaratne \& J. Hemingway) 26: 311-319 (1998)

\section{Chelating agents}

Synthesis and spectroscopic studies of 4-adipoyl-bis(1-phenyl-3-methylpyrazolone-5) as a bis-(1,3-diketone) (B.A. Uzoukwu, H. Duddeck \& S.I. Okeke) 26: 229-233 (1998) 


\section{Citrus sinensis}

Grafted sweet orange (Citrus sinensis (L.) Osbeck) influenced by variability in woodapple (Feronia limonia (L.) Swingle) rootstock (J.A. Sirisena) 26: 185-193 (1998)

\section{Cladocerans}

Studies on the population structure of zooplankton in the Kotmale reservoir (Swarna Piyasiri \& W.P.N. Chandrananda) 26: 59-76 (1998)

\section{Coconut sap}

Temperature tolerance and other properties of two ethanol producing Saccharomyces cerevisiae strains isolated from coconut toddy ( $\mathrm{S}$. Chandrani Wijeyaratne) 26: 77-91 (1998)

\section{Coconut toddy}

Temperature tolerance and other properties of two ethanol producing Saccharomyces cerevisice strains isolated from coconut toddy (S. Chandrani Wijeyaratne) 26: 77-91 (1998)

\section{Colletotrichum gloeosporioides}

Antifungal activity of Ficus racemosa leaf extract and isolation of the active compound (S.A. Deraniyagala, R.L.C. Wijesundera \& O.V.D.S. Weerasena) 26: 19-26 (1998)

\section{Conservation}

A review of the Man and the Biosphere programme in Sri Lanka (M. Watson) 26: 163-183 (1998)

\section{Corynespora cassicola}

Antifungal activity of Ficus racemosa leaf extract and isolation of the active compound (S.A. Deraniyagala, R.L.C. Wijesundera \& O.V.D.S. Weerasena) 26: $19-26$ (1998)

\section{Cowdung}

Effect of fertilizers on grain yield and grain protein content of wheat (M.A. Hasan \& A.M.A Kamal) 26: 1-8 (1998)

\section{Culex quinquefasciatus}

Identical restriction enzyme maps of the amplicon containing the Est $\alpha 2^{1}$ and Est $\beta 2^{1}$ insecticide resistance genes in Culex quinquefasciatus colonies from Saudi Arabia, Tanzania and Sri Lanka (S.H.P.P. Karunaratne \& J. Hemingway) 26: $311-319$ (1998) 


\section{Curvularia sp.}

Antifungal activity of Ficus racemosa leaf extract and isolation of the active compound (S.A. Deraniyagala, R.L.C. Wijesundera \& O.V.D.S. Weerasena) 26 19-26 (1998)

\section{Cyclopoids}

Studies on the population structure of zooplankton inthe Kotmale reservoir (Swarna Piyasiri \& W.P.N. Chandrananda) 26: 59-76 (1998)

\section{Drought}

Prediction of the effects of soil water stress on grain yield and radiation use efficiency of rice (Oryza sativa L.) using a simulation model (W.A.J.M. de Costa) $26: 101-123$ (1998)

\section{Dry zone}

Spatial interpolation of rainfall in the dry zone of Sri Lanka (B.V.R. Punyawardena \& Don Kulasiri) 26: :247-262 (1998)

\section{Education}

Tertiary education in the physical sciences (C. Dallanayake \& H.D. Gunawardhana) 26: 217-228 (1998)

\section{Embryo}

Correlation of grain characters in rice (O,yza satiun L.) (A.K.M. Golam Sarwar, M.A. Ali \& M.A. Karim) 26: 209-215(1998)

\section{Eppawela rock phosphate}

Effect of phosphorus sources and levels with particular emphasis on selectively mined Eppawela rock phosphate on vegetable production (J.D.H. Wijewardena) 26: 93-100 (1998)

\section{Esterase}

Differentiation of A \& B genome of banana and plantain (Musc spp.) by esterase enzyme (A.S.U. Liyanage, M.M.C. Manawapsema \& M.H. Mendis) 26: $125-131$ ( 1998)

\section{Ethanol}

Temperature tolerance and other properties of two ethanol producing Saccharomyces cerevisiae strains isolated from coconut toddy (S. Chandrani Wijeyaratne) 26: 77-91 (1998)

\section{Exponential correlations}

Spatial interpolation of rainfall in the dry zone of Sri Lanka (B.V.R. Punyawardena \& Don Kulasiri) 26 : 247-262 (1998) 


\section{FAB/VIS}

Flabelliferins - steroidal saponins from Palmyrah (Borassus flabellifer . L.) fruit pulp 1. Isolation by flash chromatography, quantification and saponin related activity (J. K. Nikawela, A.M. Abeysekara \& E. R. Jansz) 26: 9-18 (1998)

\section{Fauna}

A review of the Man and the Biosphere programme in Sri Lanka (M. Watson) 26: 163-183 (1998)

\section{Fertilizers}

Eflect of fertilizers on grain yield and grain protein content of wheat, (M.A. Hasan \& A. M. A. Kamal) 26: 1-8 (1998)

Effect of phosphorus sources and levels with particular emphasis on selectively mined Eppawela rock phosphate on vegetable production (J.D.H. Wijewardena) 26: $93-100$ (1998)

\section{Ficus racemosa}

Antifungal activity of Ficus racemosa leaf extract and isolation of the active compound (S.A. Deraniyagala, R.L.C. Wijesundera \& O.V.D.S. Weerasena) 26: $19-26$ (1998)

\section{Tlabellilexins}

Flabelliferins - steroidal saponins from palmyrah (Borassus flabellifer L.) fruit pulp 1. Isolation by flash chromatography, quantification and saponin related activity (J. K. Nikawela, A.M. Abeysekara \& E. T. Jansz) 26: 9-18 (1998)

Flabelliferins, steroidal saponins from palmyrah (Borcussus flabellifer L.) fruit pulp II. Preliminary investigations of effect on yeast and selected bacteria (J.K. Nikawala, S.C. Wijeyaratne, E.R. Jansz \& A.M. Abeysekera) 26: 141-150 (1998)

\section{Flors}

A review of the Man and the Biosphere programme in Sri Lanka (M. Watson) 26: 163-183 (1998)

\section{Froth test}

Flabelliferins - steroidal saponins from palmyrah (Borassus flabellifer L.) fiuit pulp 1. Isolation by flash chromatography, quantification and saponin related. activity (J. K. Nikawela, A.M. Abeysekara \& E. R. Jansz) 26: 9-18 (1998)

\section{Funds}

Research in the field of medical sciences (Saroj Jayasinghe \& Geethika Yapa) 26: $275-281$ (1998) 


\section{Fungal flora}

Histology and fungal tlora of shot-hole borer beetle (Xyleborus fornicatus) galleries in tea (Camellia sinensis) (N.S. Kumar, P. Hewavitharanage \& N.K.B. Adikaram) 26: 195-207 (1998)

\section{Fusarium sp.}

Antifungal activity of Ficus racemosa leaf extract and isolation of the active compound (S.A. Deraniyagala, R.L.C. Wijesundera \& O.V.D.S. Weerasena) 26: 19-26 (1998)

\section{Gene amplification}

Identical restriction enzyme maps of the amplicon containing the Esto $2^{\prime}$ and Est $\beta 2$ ' insecticide resistance genes in Culex quinquefasciatus colonies from Saudi Arabia, Tanzania and Sri Lanka (S.H.P.P. Karunaratne \& J. Hemingway) 26: $311-319$ (1998)

\section{Genomes}

Differentiation of A \& B genome of banana and plantain (Musa spp.) by esterase enzyme (A.S.U. Liyanage, M.M.C. Manawa prema \& M.H. Mendis) 26: 125-131 (1998)

\section{Grafting}

Grafted sweet orange \{Citrus sinensis (L.) Osbeck\} influenced by variability in woodapple \{feronia limonia (L.) Swingle\} rootstock (J.A. Sirisena) 26: 185-193 (1998)

\section{Grain character}

Correlation of grain characters in rice (Oryza sativa L.) (A.K.M. Golam Sarwar, M.A. Ali \& M.A. Karim) 26: 209-215 (1998)

\section{Grain yield}

Effect of fertilizers on grain yield and grain protein content of wheat (M.A. Hasan \& A. M. A. Kamal) 26: 1-8 (1998)

Effect of nitrogen on yield, yield components and contribution from the preanthesis assimilates to grain yield of three photosensitive rice (Oryza sativa L.) cultivars (N. Ahmed, M. Eunus, M.A. Latif, Z.U. Ahmed \& M. Rahman) 26: 3545 (1998)

\section{Haemolysis}

Flabelliferins - steroidal saponins from palmyrah (Borassus flabellifer L.) fruit pulp 1. Isolation by flash chromatography, quantification and saponin related activity (J. K. Nikawcla, A.M. Abeysekara \& E.R. Jansz) 26: 9-18 (1998) 


\section{Hambantota}

Variation of surface winds at Hambantota fiom April 1990 to March 1991 (Lareef Zubair) 26: 235-245 (1998)

\section{Histology}

Histology and fungal flora of shot-hole borer beetle (Xyleborus fornicatus) galleries in tea (Camellia sinensis) (N.S. Kumar, P. Hewavitharanage \& N.K.B. Adikaram) 26: 195-207 (1998)

\section{Humid forests}

A review of the Man and the Biosphere programme in Sri Lanka (M. Watson) 26: 163-183 (1998)

\section{Information centres}

Contribution of NARESA towards development of scientific information resources and services (N.U. Yapa) 26:321-332 (1998)

\section{Insecticide resistance}

Identical restriction enzyme maps of the amplicon containing the Esto.2' and Est 32 insecticide resistance genes in Culex quinquefusciatus colonies from Saudi Arabia, Tanzania and SriLanka (S.H.P.P. Kan una atme\& J. Heningway) 26:311-319(1998)

\section{International co-operation}

International co-operation in Science \& Technology (Swarna P. Prelis) 26: 249-323 (1998)

\section{Isozymes}

Differentiation of A \& B genome of banana and plantain (Musa spp.) by esterase enzyme (A.S.U. Liyanage, M.M.C. Manawaprema \& M.T. Mendis) 26: $125-131(1998)$

\section{Kernel}

Correlation of grain characters in rice (Oryza sativa L.) (A.K.M. Golam Sarwar, M.A. Ali \& M.A. Karim) 26: 209-215 (1998)

\section{Kotmale reservoir}

Species composition and population dynamics of the phytoplankton community in Kotmale reservoir (Nishanthi Perera \& Swarna Piyasiri) 26: 293-309 (1998)

\section{Medical sciences}

Research in the field of medical sciences (Saroj Jayasinghe \& Geethika Yapa) 26: $275-281$ (1998) 


\section{Medicinal plants}

Antibacterial activity of some medicinal plants of Sri Lanka (C.M. Hewage, B.M.R. Bandara, V. Karunaratne, G.P. Wannigama, M.R.M. Pinto \& D.S.A. Wijesundara) 26: 27-34 (1998)

\section{Meloidogyne spp.}

Preliminary studies on the prevalence and controlling efficiency of Pasteuria penetrans, a parasite of Meloidogyne spp. in Srj Lanka (D).M. de Costa, H.N.P. Wijayagunasekara, C.P. Alahakoon \& A.M. Pliyantha Bandara) 26: $47-57(1998)$

\section{Microcystis blooms}

Species composition and population dynamics of the phytoplankton community in Kotmale reservoir (Nishanthi Perera \& Swarna Piyasiri) 26: 293-309 (1998)

\section{Models}

Spatial interpolation of rainfall in the dry zone of Sri Lanka (B.V.R. Punyawardena \& Don Kulasiri) 26: 247-262 (.1998)

\section{Monacrosporium ambrosium}

Histology and fungal flora of shot-hole borer beetle (Xyleborus fornicatus) galleries in tea (Camellia sinensis) (N.S. Kumar, P. Hewavitharanage \& N.K.B. Adikaram) 26: 195-207 (1998)

\section{Mosquitoes}

Identical restriction enzyme maps of the amplicon containing the Esto $2^{\prime}$ and Est $\beta 2^{\prime}$ insecticide resistance genes in Culex quinquefusciatus colonies from Saudi Arabia, Tanzania and Sri Lanka (S.H.P.P. Karunaratne \& J. Hemingway) 26: $311-319$ (1998)

\section{Musa spp.}

Differentiation of A \& B genome of banana and plantain (Musa spp.) by esterase enzyme (A.S.U. Liyanage, M.M.C. Manawaprema \& M.H. Mendis) 26 : 125-131 (1998)

\section{Nitrogen}

Effect of nitrogen on yield, yield components and contribution from the preanthesis assimilates to grain yield of three photosensitive rice (Oryza sativa L.) cultivars (N. Ahmed, M. Eunus, M.A. Latif, Z.U. Ahmed \& M. Rahman) 26:3545 (1998) 


\section{Oryza sativa L.}

Effect of nitrogen on yield, yield components and contribution from the preanthesis assimilates to grain yield of three photosensitive rice (Oryza sativa L.) cultivars (N. Ahmed, M. Eunus, M.A. Latif, Z.U. Ahmed \& M. Rahman) 26: 35$45(1998)$

\section{Palmyrah}

Flabelliferins - steroidal saponins from palmyrah (Borassus flabellifer L.) fruit pulp 1. Isolation by flash chromatography, quantification and saponin related activity (J. K. Nikawela, A.M. Abeysekara \& E. R. Jansz) 26: 9-18 (1998)

Flabelliferins, steroidal saponins from palmyrah (Borassus flabellifer L.) fruit pulp II. Preliminary investigations of effect on yeast and selected bacteria. (J.K. Nikawala, S.C. Wijeyaratne, E.R. Jansz \& A.M. Abcysekera) 26: 141-150 (1998)

\section{Pasteuria penetrans}

Preliminary studies on the prevalence and controlling efficicncy of Pasteuria penetrans, a parasite of Meloidogyne spp. in Sri Lanka (D.M. de Costa, H.N.P. Wijayagunasekara, C.P. Alahakoon \& A.M. Priyantha Bandara) 26: 47-57(1998)

\section{Periodicity}

Species composition and population dynamics of the phytoplankton community in Kotmale reservoir (Nishanthi Perera \& Swarna Piyasiri) 26: 293-309 (1998)

\section{Phosphates}

Effect of phosphorus sources and levels with particular em phasis on selectively mined Eppawela rock phosphate on vegetable production (J.D.H. Wijewardena) 26: $93-100$ (1998)

\section{Physical science}

Tertiary education in the physical sciences (C. Dahanayake \& H.D. Gunawardhana) 26: 217-228 (1998)

\section{Phytoplankton community}

Species composition and population dynamics of the phytoplankton community in Kotmale rescrvoir (Nishanthi Perera \& Swarna Piyasiri) 26: 293-309 (1998)

\section{Pole bean}

Effect of phosphorus sources and levels with particular emphasis on selectively mined Eppawela rock phosphate on vegetable production (J.D.H. Wijewardena) 26: 93-100 (1998) 


\section{Potato}

Effect of phosphorus sources and levels with particular emphasis on selectively mined Eppawela rock phosphate on vegetable production (J.D.H. Wijewardena) 26: 93-100 (1998)

\section{Pre-anthesis assimilates}

Effect of nitrogen on yield, yield components and contribution fiom the preanthesis assimilates to grain yield of three photosensitive rice (Oryza sativa L.) cultivars (N. Ahmed, M. Eunus, M.A. Latif, Z.U. Ahmed \& M. Rathman) 26: 354.5 (1998)

\section{Protected area}

A review of the Man and the Biosphere programme in Sri Lanka (M. Watson) 26: $163-183$ (1998)

\section{Protein}

Effect of fertilizers on grain yield and grain protein content of wheat (M.A. Hasan \& A.M.A. Kamal) 26: 1-8 (1998)

\section{Pyrazolone}

Synthesis and spectroscopic studies of 4-adipoyl-bis(1-phenyl-3-methylpyrazolone-5) as a bis-(1,3-diketone) (B.A. Uzoukwu, H. Duddeck \& S.I. Okeke) 26: $229-233$ (1998)

\section{Population structure}

Studies on the population structure of zooplankton in the Kotmale reservoir (Swarna Piyasiri \& W.P.N. Chandrananda) 26: 59-76 (1998)

\section{Radiation use efficiency}

Prediction of the effects of soil water stress on grain yield and radiation use efficiency of rice (Oryza sativa L.) using a simulation model (W.A.J.M. de Costa) 26: 101-123 (1998)

\section{Rainfall}

Spatial interpolation of rainfall in the dry zone of Sri Lanka (B.V.R. Punyawardena \& Don Kulasiri) 26: 247-262 (1998)

\section{Research funding}

Developments in biotechnology - progress, problems and prospects (Ranjan Ramasamy) 26: 283-292 (1998) 


\section{Research}

Animal health research in Sri Lanka : a review of the past, future priorities and constraints (M.C.L. de Alwis) 26: 151-161 (1998)

Research in the field of medical sciences (Saroj Jayasinghe \& Geethika Yapa) 26: 325-331 (1998)

\section{Restriction enzyme maps}

Identical restriction enzyme maps of the amplicon containing the Esto.2 ${ }^{1}$ and Est $\beta 2^{1}$ insecticide resistance genes in Culex quinquefasciatus colonies from Saudi Arabia, Tanzania and Sri Lanka (S.H.P.P Karunaratne \& J. Hemingway 26: 311-319 (1998)

\section{Rice}

Correlation of grain characters in rice (Oryza sativa L.) (A.K.M. Golam Sarwar, M.A. Ali \& M.A. Karim) 26: 209-215 (1998)

Effect of nitrogen on yield, yield components and contribution from the preanthesis assimilates to grain yield of three photosensitive rice (Oryza sativa L.) cultivars (N. Ahmed, M. Eunus, M.A. Latif, Z.U. Ahmed \& M. Rahman) 26: 3545 (1998)

Prediction of the effects of soil water stress on grain yield and radiation use cfficiency of Rice (Oryza sativa L.) using a simulation model (W.A.J.M. de Costa) 26: 101-123 (1998)

\section{Rock Phosphate}

Effect of phosphorus sources and levels with particular emphasis on selectively mined Eppawela rock phosphate on vegetable production:(J.D.H. Wijewardena) 26: 93-100 (1998)

\section{Root-knot nematodes}

Preliminary studies on the prevalence and controlling efficiency of Pasteuria penetrans, a parasite of Meloidogyne spp. in Sri Lanka (D.M. de Costa, H.N.P. Wijayagunasekara, C.P. Alahakoon \& A.M. Priyantha Bandara) 26: 47-57(1998)

\section{Rootstock variability}

Grafted sweet orange (Citrus sinensis (L.) Osbeck) influenced by variability in woodapple (Feronia limonia (L.) Swing]e) rootstock (J.A. Sirisena) 26: 185-193 (1998) 


\section{Tomato}

Effect of phosphorus sources and levels with particular emphasis on selectively mined Eppawela rock phosphate on vegetable production (J.D.H. Wijewardena) 26: 93-100 (1998)

\section{Triple Superphosphate}

Effect of phos phorus sources and levels with particular em phasis on selectively mined Eppawela rock phosphate on vegetable production (J.D.H. Wijewardena) 26: 93-100 (1998)

\section{Universities}

Tertiary education in the physical sciences (C. Dahanayake \& H.D. Gunawardhana) 26: 217-228 (1998)

\section{Urea}

Effect of fertilizers on grain yield and grain protein content of wheat (M.A. Hasan \& A.M.A. Kamal) 26: 1-8 (1998)

\section{Vegetables}

Effect of phosphorus sources and levels with particularemphasis on selectively mined Eppawela rock phosphate on vegetable production (J.D.H. Wijewardena) 26: 93-1.00 (1998)

\section{Velocity}

Variation of surface winds at Hambantota from April 1990 to March 1991 (Lareef Zubair) 26: 235-245 (1998)

\section{Veterinary sciences}

Animal health research in Sri Lanka : a review of the past, future priorities and constraints (M.C.L. de Alwis) 26: 151-161 (1998)

\section{Water stress}

Prediction of the effects of soil water stress on grain yield and radiation use efficiency of rice (Oryza sativa L.) using a simulation model (W.A.J.M. de Costa) 26: 101-123 (1998)

\section{Wheat}

Effect of fertilizers on grain yield and grain protein content of wheat (M.A. Hasan \& A.M.A. Kamal) 26: 1-8 (1998)

\section{Wind}

Variation of surface winds at Hambantota from April 1990 to March 1991 (Lareef 'Zubair) 26: 235-245 (1998) 


\section{Woodapple}

Grafted sweet orange \{Citrus sinensis (L.) Osbeck\} influenced by variability in woodapple \{Feronia limonia (L.) Swingle\} rootstock (J.A. Sirisena) 26: 185-193 (1998)

\section{Xyleborus fornicatus}

Histology and fungal flora of shot-hole borer beetle (Xyleborus fornicatus) galleries in tea (Camellia sinensis) (N.S. Kumar, P. Hewavitharanage \& N.K.B. Adikaram) 26: 195-207 (1998)

\section{Yeast}

Temperature tolerance and other properties of two ethanol producing Saccharomyces cerevisiae strains isolated from coconut toddy (S. Chandrani Wijeyaratne) 26: 77-91 (1998)

\section{Zooplankton}

Studies on the population structure of zooplankton in the Kotmale reservoir (Swama Piyasiri \& W.P.N. Chandrananda) 26: 59-76 (1998)

\section{Zymograms}

Differentiation of A \& B genome of banana and plantain (Musa spp.) by esterase enzyme (A.S.U. Liyanage, M.M.C. Manawaprema \& M.H. Mendis) 26: 125-131 (1998) 
JOURNAL OF THE

NATIONAL SCIENCE FOUNDATION

OF SRI LANKA

\section{GUIDELINES FOR CONTRIBUTORS}

\section{SCOPE}

The journal of the National Science Foundation of Sri Lanka publishes the results of research in all aspects of science and technology, in the form of Articles, Short Communications, Reviews and Correspondence.

\section{TYPES OF PAPERS CONSIDERED FOR PUBLICATION}

Articles are full length papers presenting complete descriptions of original research or technological achievements. Manuscripts that do not merit publication as full papers may be considered, where appropriate, for publication as Short Communications. Short Communications should not exceed four printed pages of the journal including not more than one figure and table. Reviews are critical evaluations of selected fields of science and technology and should be prepared in consultation with the Editorial Board. Correspondence about one or more articles in a recent issue of the journal may also be published.

\section{GUIDE TO PREPARATION OF MANUSCRIPTS}

The authors and their typists should consult a recent issue of the journal in order to familiarize themselves with the conventions and layout of articles.

\section{Script}

The script should be free of errors and typewritten using double-spacing throughout on one side of $\mathrm{A} 4$ size white bond paper, leaving at least $3 \mathrm{~cm}$ margins on either side and liberal spacing at the top and bottom of each page. Sheets should be numbered consecutively. The journal will also accept manuscripts in a floppy diskette in Word Perfect or MS Word format. Sending a copy in diskette form, in addition to the typescript, will help processing of the manuscript.

\section{Length and Style}

While there is no prescribed maximum length for a paper, it is required that the paper should be written clearly and concisely. The style of writing should conform to acceptable English usage. Slang, jargon, unauthorized abbreviations, abbreviated phrasings and the like, should be avoided. In general, the impersonal form should be used. 


\section{Manuscript Layout}

Manuscripts for articles should be organized as follows: Abstract, Key words, Introduction, Methods and Materials, Results, Discussion, Acknowledgement, References. Results and Discussion can be merged in a short communication.

Each page of the paper should be numbered. A separate title page should contain the title of the paper, the name(s) of the author(s), and their affiliation(s). The name and address of the corresponding author should be stated. If the paper was based on material presented at a meeting, this fact should be indicated in a footnote on the title page.

Title: The title of the paper should accurately reflect its content and must not excecd 100 characters in length. A short running title of upto 40 characters should be provided.

Abstract: An abstract of upto 250 words should convey the scope of the paper and be as informative as possible. The abstract should not contain any references and it must be able to stand on its own without reference to the main text to enable it to be used without modification in abstracting journals. It should outline objectives and methodology together with important results and conclusions. Reviews should begin with an appropriate summary of upto 150 words.

Key Words: Upto ten key words, that could be used for indexing, should be provided. Words that are used as subject headings in indexing journals are prefierred.

Introduction: 'This should state the reasons for performing the work with brief' reference to relevant previous work. Reference should be made to previously published abstracts and if the work had been presented at meetings, in a footnote.

Methods and Materials: New methods may be described in detail with an indication of their limitations. Established methods can be mentioned with appropriate references. Sufficient detail should be included to allow direct repetition of the work by others. Where human subjects are involved, they should be referred to by number or fictitious names. A paper reporting the results of experimental investigations on human subjects or on animals must include a statement, under Methods and Materials, to the effect that the relevant national or other ethical guidelines have been adhered to. Statistical analyses done should be mentioned where applicable.

Results: The results should be concisely and logically presented. Only data essential for the main conclusions emerging from the study should be included. 
Interpretation of data should be left to the Discussion section. Presentation of the same results in the figures and text should be avoided

Discussion: Long, rambling discussions should be avoided. The discussion should deal with the interpretation of results without repeating information already presented in results. It should logically relate new findings to old ones. Unqualified statements and conclusions not completely supported by data should be avoided. All hypotheses should be clearly identified as such.

Acknowledgement: Acknowledgements should be brief and made for specific scientific and technical assistance only and not for routine help in preparing manuscripts. If a significant part of the research was performed in an institution other than in those indicated by the authors' affiliations given in the title page, this fact should be acknowledged.

References: References to the literature must be indicated in the text and tables in serial order by a small superscript number in Arabic numerals. The list of references in numerical order must be placed at the end of the manuscript. Unpublished data and personal communications should not be listed under references but may be mentioned in the text. Reference to work 'in press' implies its acceptance for publication and may be listed under references.

In each reference, all the initials of the author must be given after the surname. The year of publication should follow in parentheses. This should be followed by the full title of the referred publication. When journal articles are listed, the journal name should be given in full and it should be underlined to indicate italic type and followed by the volume number in bold type, the issue number in parentheses and then the inclusive pages. When books are listed, the order should be : author(s), year, book title, volume number, edition, pagination/inclusive pages, publisher and place of publication. The book title should be underlined to indicate italic type. When sections of a book are listed, the order should be: author(s) of section, year, the title of the section, title of the book, edition, inclusive pages, publisher and place of publication.

Examples of correct forms of references are given below.

\section{Journal}

(1) Standard article

Kumar N.S., Hewavitharanage P. \& Adikaram N.K.B. (1998). Histology and fungal flora of shot-hole borer beetle (Xyleborus fornicatus) galleries in tea (Camelia sinensis). Journal of the National Science Council of Sri Lanka 26(3): 195-207 
Scandinavian Society for Clinical Chemistry and Clinical Physiology Committee on Enzymes (1976). Recommended method for the determination of gamma-glutamyltransferase in blood. Scandinavian Journal of Clinical \& laboratory Investigation 36:119-125.

Books and other monographs

Chapter in book

Webber M.D. (1991). Resource recovery through unconventional uses of sludge. In: Alternative uses for sewage sludge. (Ed. J.E. Hall) pp. 343358. Pergamon Press, Oxford.

(4)

\section{Agency publication}

Geological Survey \& Mines Bureau of Sri Lanka (1995). Geology of the country around Battulu Oya \& Puttalam. Geological Survey \& Mines Bureau, Colombo.

Footnotes: 'These should be included only if they are indispensable. They should be indicated in the text by small superior symbols and listed on a separate page in the manuscript.

Abbreviations and Symbols: Unless common, these should be defined when first used, and not included in the abstract. The SI System of units should be used wherever possible. If measurements were made in units other than SI, the clata should be reported in the same units followed by SI units in brackets. e.g. 5290 fit. (1610m).

Formulae and Equations: Equations should be typewritten and quadruple spaced. They should be started on the left margin and the number placed in parentheses to the right of the equation.

Nomenclature: Scientific names of plants and animals will be printed in italics, and should be either underlined or typed in italics in the manuscript. In the first citation, genus, species and authority must be given. e.g Culex quinquefasciatus Say. In later citations, the generic name may be abbreviated. e.g. Cx. quinquefasciatus.

\section{Tables}

Tables should be clear and intelligible without reference to the text, and should not repeat data available elsewhere in the paper. They should be typed on A4 size paper 
and numbered consecutively with Arabic numerals. If a table must be continued, a second sheet should be used and all the headings repeated.

The number of columns or rows in each table should be minimized. Each table should have a title which makes its general meaning clear without reference to the text. All table columns should have explanatory headings. Units of measurement, if any, should be indicated in parentheses in the heading of each colum.n. Vertical lines should not be used and horizontal lines should be used only in the heading and at the bottom of the table. Footnotes to tables should be placed directly below the table and should be indicated by superscript lower case italic letter's ( $a, b$, c, etc.). The preferred position of tables should be indicated in pencil in the manuscript.

\section{Figures (Illustrations)}

Figures (Illustrations) should be kept to a minimum and their total should not exceed ten. If previously published illustrations are essential, the copyright holder's written permission should be obtained. All illustrations are considered as figures, and each graph, drawing or photograph should be numbered in sequence with Arabic numerals. Original illustrations should not carry any lettering. The required Jettering should be indicated on a photocopy of the illustration. The printer will insert the lettering during the process of printing. Symbols and abbreviations in the lettering should correspond accurately with those in the legend and text.

Photocopies are acceptable as duplicates. Figures should be planned to fit the printed page $(12 \times 17 \mathrm{~cm})$. Figures must be drawn in Indian ink on plain white paper or board or tracing paper, not larger than $20 \times 30 \mathrm{~cm}$.

Each figure should carry a legend so written that the general meaning of the figure can be understood without reference to the text. Figure Jegends should be typed with double-spacing on a separate sheet and placed at the end of the paper. The maximum number of words per legend should be 40 . Where magnifications are used, they should be stated. 'The approximate position for each figure should be indicated in the margin of the text.

Illustrations in colour are accepted only very exceptionally. The author may be requested to meet part or in full, the cost of reproducing and printing colour illustrations.

Graphs should be plotted on tracing paper. Grid lines that are to be shown in the engraving should be inked in black. The caption of each axis should be lettered in pencil parallel to the axis in photocmpies.

Only unmounted high quality glossy photographs are acceptable. Magnification should be indicated with a scale line on the photograph. The author's name and figure number should be given on the back of each photograph. 


\section{SUBMISSION OF MANUSCRIPT}

The authors may suggest the names of five local or foreign referees when submitting their manuscript. Referees should not be from the institution where the work was carried out. The addresses and institutional affiliations of the suggested referees should be supplied.

Manuscripts should be submitted in triplicate, including illustrations to:

The Editorial Office

Journal. of the National Science Foundation of Sri Lanka

National Science Foundation

47/5, Maitland Place,

Colombo 7.

SRI LANKA

Manuscripts are accepted on the understanding that they will be reviewed prior to acceptance and they have not been submitted for publication elsewhere. The decision of the Editorial Board on publication is final. Papers may be subject to editorial revision in order to improve presentation. Authors submitting Research Articles must furnish a signed statement on authorship responsibility and financial interest in the format given below.

Twenty reprints will be supplied free of charge to the authors. Additional reprints may be ordered at cost from NSF.

\section{AUTHORS' RESPONSIBILITY AND FINANCIAL DISCLOSURE}

Each author must read and sign the statement of (1) authorship responsibility; (2) financial disclosure. Photocopies of this form may be used for this purpose.

\section{Authorship responsibility}

I/We certify that I/We have participated sufficiently in the conception, design and execution of this work and the analysis of the data (where applicable) as well as in the writing of the manuscript, to take public responsibility for it.

I/We certify also that the material reported here represents original work carried out by me/ourselves.

Neither this manuscript nor one with substantially similar content under my/our authorship has been published or is being considered for publication elsewhere, except as described in an annexure. 
I/We attest also that I/We shall produce the original data upon which the manuscript is based for examination by the editors or their assignees should they request it.

\section{Financial disclosure}

I/We certify that $I /$ We have no affiliation with or financial involvement in any organization or entity with a direct financial interest in the subject matter or materials discussed in the manuscript (e.g. consultancies, employment, honoraria, stock ownership).

\section{Author's signature}

We hereby jointly and severally take responsibility for authorship of the paper submitted for publication in the Journal of the National Science Foundation of Sri Lanka and, we also certify jointly and severally agreement with the financial disclosure statement shown in para 2 above. 